COMMONWEALTH OF MASSACHUSETTS

ADMINISTRATIVE OFFICE

OF THE

TRIAL COURT

BOSTON 02108

GOVERMENT DOCUMENTS

COLLECTION

OCT \& S 2002

University of Massachusetts

Depository Copy

\title{
CHILD SUPPORT GUIDELINES
}

The attached CHILD SUPPORT GUIDELINES supersede any previous Guidelines and are effective February 15, 2002.

\author{
Barbara A. Dortch-Okara
}

Chief Justice for Administration and Management 


\section{Digitized by the Internet Archive}

in 2014 


\title{
COMM ONWEALTH OF MASSACHUSETTS
}

\author{
ADMINISTRATIVE OFFICE \\ OF THE TRIAL COURT
}

\section{CHILD SUPPORT GUIDELINES}

\begin{abstract}
N.B. THESE GUIDELINES APPLY TO CURRENT CHILD SUPPORT ONLY. THEY DO NOT APPLY TO ALIMONY, THE DIVISION OF MARITAL PROPERTY, THE PAYMENT OF ARREARS, RESTITUTION, OR REIMBURSEMENT, NOR DO THEY APPLY WHERE THE PARTIES HAVE MADE AN AGREEMENT WHICH IS APPROVED BY THE COURT AND IS FOUND BY THE COURT TO BE FAIR AND REASONABLE, AND MAKES ADEQUATE PROVISION FOR THE SUPPORT OF THE CHILD.
\end{abstract}

THERE SHALL BE A PRESUMPTION THAT THESE GUIDELINES APPLY, ABSENT AGREEMENT OF THE PARTIES, IN ALL CASES SEEKING THE ESTABLISHMENT OR MODIFICATION OF A CHILD SUPPORT ORDER. A SPECIFIC, WRITTEN FINDING THAT THE GUIDELINES WOULD BE UNJUST OR INAPPROPRIATE AND THAT THEBEST INTERESTS OF THE CHILD HAVE BEEN CONSIDERED IN A PARTICULAR CASE SHALL BE SUFFICIENT TO REBUT THE PRESUMPTION IN THAT CASE.

\section{THESE REVISED GUIDELINES, IN AND OF THEMSELVES, DO NOT CONSTITUTE A SUFFICIENT CHANGE OF CIRCUMSTANCES TO WARRANT A MODIFICATION OF THE CHILD SUPPORT ORDER}

The child support guidelines are formulated to be used by the justices of the Trial Court, whether the parents of the children are married or unmarried, in sctting temporary, permanent or final orders for current child support, in deciding whether to approve agreements for child support, and in deciding cases that are before the court to modify existing orders. A modification may be allowed upon showing a discrepancy of $20 \%$ or more between an established order and a proposed new order calculated under these guidelines. The presumption establishing a proposed new order may be rebutted in cases where the amount of support required under the guidelines is due to the fact that the amount of the current support order resulted from a rebuttal of the guideline amount or by an allowance of an agreement of the parties and there has not been a change in the circumstances which resulted in a rebuttal of the guideline amount. The guidelines are intended to be of assistance to members of the bar and to litigants in determining what level of payment would be expected of them given the relative income levels of the parties. In all orders where an order for child support is requested, a guideline worksheet must be filled out, regardless of the income of the parties.

In establishing these guidelines, due consideration has been given to the following principles:

1) To minimize the economic impact on the child of family breakup;

2) To encourage joint parental responsibility for child support in proportion to, or as a pcrecntage of income;

3) To provide the standard of living the child would have enjoyed had the family been intact:

4) To meet the child's survival needs in the first instance, but to the cxtent cither parent cnjoys a higher standard of living to entitle the child to enjoy that higher standard;

5) To protect a subsistence level of income of parents at the low end of the income range whether or not they are on public assistance;

6) To take into account the non-monctary contributions of both the custodial and non-custodial parents;

7) To minimize problems of proof for the partics and of administration for the courts:

8) To allow for orders and wage assignments that can be adjusted as income increases or decreases. 


\section{INCOME DEFINITION}

A. For purposes of these guidelines income is defined as gross ineome from whatever source. Those soure es include, but are not limited to, the following:

1) salaries and wages (ineluding overtime and tips) and ineome from self-employment (except in certain instances, see B below)

2) commissions

3) severance pay

4) royalties

5) bonuses

6) interest and dividends

7) income derived from business/partnerships

8) social security

9) veterans' benefits

10) insurance benefits (including those received for disability and personal injury)

11) workers' compensation

12) unemployment compensation

13) pensions

14) annuities

15) ineome from trusts

16) capital gains in real and personal property transaetions to the extent that they represent a regular souree of income

17) spousal support received from a person not a party to the order

18) contractual agreements

19) perquisites or in kind compensation to the extent that they represent a regular source of ineome

20) unearned income of children (in the court's discretion)

21) ineome from life insurance or endowment contracts

22) income from interest in an estate (direet or through a trust)

23) lottery or gambling winnings received either in a lump sum or in the form of an annuity

24) prizes or awards

25) net rental ineome

26) funds received from earned income credit

B. In individual cases, the court may choose to disregard overtime income or income derived from a second job. However, consideration of such ineome may be appropriate in eertain instanees such as those where such ineome constituted a regular souree of income when the family was intact.

\section{FACTORS TO BE CONSIDERED IN SETTING THE CHILD SUPPORT ORDER}

\section{A. RELATIONSHIP TO ALIMONY OR SEPARATE MAINTENANCE PAYMENTS}

So long as the standard of living of the ehildren is not diminished, these guidelines do not preclude the court from deciding that any order be denominated in whole or in part as alimony or as a separate maintenanee payment. 1t is the responsibility of counsel representing the parties to present the tax consequences of proposed orders to the court.

\section{B. CLAIMS OF PERSONAL EXEMPTIONS FOR CHILD DEPENDENTS}

In setting a support order, the eourt may make an order regarding the elaims of personal exemptions for child dependents between the parties to the extent permitted by law. 


\section{MINIMUM AND MAXINUM LEVELS}

The guidelines recognize the principle that, in many instances, to maintain a domicile and a reasonable standard of living for the minor children, the custodial parent will choose to work. In those cases, a disregard of gross income of the custodial parent is to be applied up to a maximum of $\$ 20,000$. The formula in these guidelines is intended to be adjusted where the income of the custodial parent exceeds the $\$ 20,000$ disregard after consideration of day carc expenses.

These guidelines are also intended to ensurc a minimum subsistence level for those non-custodial parents whose income is less than $\$ 100$ per week. However, it is the obligation of all parents to contribute to the support of their children. To that end, in all cases, a minimum order of $\$ 80.00$ ( $\$ 18.46$ per week) per month should enter. This minimum should not be construed as limiting the court's ability to set a higher order, should circumstances permit.

Where the court makes a determination that either or both of the parties is either purposely unemployed or underemployed, the section of this guideline entitled ATTRIBUTION OF INCOME should be consulted.

These guidelines are not meant to apply where the combined gross income of the parties exceeds $\$ 135,000$ or where the gross income of the non-custodial parent exceeds $\$ 100,000$. In cases where income exceeds these limits, the court should consider the award of support at the $\$ 100,000 / \$ 135,000$ level as a minimum presumptive level of support to be awarded. Additional amounts of child support may be awarded at the judge's discretion.

\section{CUSTODY AND VISITATION}

\section{1) Custody}

These guidelines are based upon traditional custody and visitation arrangements. Where the parties agree to shared physical custody or the court determines that shared physical custody is in the best interests of the children, these guidelines are not applicable. The guidelines are also not meant to apply for cases in which there is split physical custody, i.e., each parent has physical custody of one or more children.

\section{1) Visitation}

These guidelines recognize that children must be allowed to enjoy the society and companionship of both parents to the greatest extent possible. The court may adjust the amount of child support beyond the 2 percent range (see Basic Order, Section III. A.) after taking into consideration the parties' actual time sharing with the children and the relative resources, cxpenses, and living standards of the two households.

In some instances the non-custodial parent may incur extraordinary travel-related expenses in order to exercise court ordered visitation rights. To foster parental involvement with the children, the court may wish to consider such extraordinary expenses in determining the support order.

\section{E. CHILD CARE CREDIT}

The basic child support obligation set out in the guidelines includes the non-custodial parent's share of child care expenses. Child care expenses are not secn as a scparate support itcm and responsibility for them resides with the custodial parent. 
The reasonable cost of child care (costs as defined by 26 USC 21, Internal Revenue Service Code Section 21) actually paid is to be subtracted from the custodial parent's gross income before the disregard formula is applied.

\section{F. AGE OF THE CHILDREN}

To reflect the costs of raising children, age has been broken down into three groups: $0-12,13-18$, and over 18. A single adjustment to the basic order should be made bascd on the age of the oldest child for whom support is to be ordered. The support order where the oldest child is 12 or under should be the basic support order according to the schedule. Where the oldest child is between the ages of 13 and 18 . the order should be increased by 10 percent of the basic order amount. For cases involving children over the age of 18 , to the extent permitted by the General Laws, the amount of the order, if any, will be left to the Court's discretion.

Where the parties file an agreement with the court that allows for private payment between the parties, it is suggested that the incremental age issue be addressed in the agreement.

\section{G. HEALTH INSURANCE, UNINSURED, AND EXTRAORDINARY MEDICAL EXPENSES}

\section{1) Health Insurance}

When the court makes an order for child support, the court shall determine whether the obligor under the order has health insurance on a group plan available to him/her through an employer or organization or has health insurance or other health coverage available to him/her at reasonable cost that may be extended to cover the child for whom support is ordered. When the court makes a determination that the obligor has such coverage, the court shall include in the support order a requirement that the obligor exercise the option of additional coverage in favor of such child, unless the obligee has already provided such coverage for the child at a lesser cost (except for health insurance funded under public assistance programs), or has and prefers to continue such coverage irrespective of cost.

If family health coverage is to be provided by the obligor, the support order should be reduced by one half the cost of family coverage. It is the responsibility of the obligor under the support order who is seeking such a reduction in the order to produce proof satisfactory to the court of the existence of such family coverage under the plan, or no such reduction shall be allowed. However, there shall be no reduction if the obligor has a pre existing family health ins urance policy which could be amended to name the additional dependents to the policy at no cost to the obligor. Should health insurance not be provided for any period for which it is ordered, the credit for the premium payment shall be revoked and the order shall be increased by the amount of the credit during the pcriod of noncompliance.

If family health coverage is provided by the obligee, the support order should be increased by one half the cost of the coverage. It is the responsibility of the obligee who is seeking an increase in the order to produce proof satisfactory to the court of the existence of such family covcrage under the plan. or no such increase shall be allowed. However, there shall be no increase if the obligee has a preexisting family health insurance policy which could be amended to name the additional dependents at no cost to the obligee. Should health insurance not be provided for any period for which it is ordcred, the increase allowed for the premium payment shall be revoked and the order shall be decreased during the period when health insurance is not provided.

\section{2) Routine Uninsured Medical and Dental Expenses}

The custodial parent shall be responsible for the payment of the first $\$ 100$ per child per year for routine medical and dental expenses. For amounts above that limit, the court shall allocate costs on a case by case basis. No reduction in the child support order should be allowed. 


\section{3) Uninsured Extraordinary Medical and Dental Expenses}

The payment of uninsured extraordinary medical and dental expenses incurred by the minor children, absent agreement of the parties, shall be treated on a case by case basis.

(Example: orthodontia, psychological/psychiatric counseling, etc.) In such cases, where the court makes a determination that such medical and dental services are necessary and are in the best interests of the child, consideration toward a reduction in the child support order should be given.

\section{A. ATTRIBUTION OF INCOME}

If the court makes a determination that either or both parties is earning substantially less than he or she could through reasonable effort, the court may consider potential earning capacity rather than actual earnings. In making this determination, the court shall take into consideration the education, training, and past employment history of the party. These standards are intended to be applied where a finding has been made that the party is capable of working and is unemployed, working part-time or is working a job, trade, or profession other than that for which he/she has been trained.

This determination is not intended to apply to a custodial parent with children who are under the age of six living in the home.

\section{PRIOR ORDERS FOR SUPPORT}

To the extent that prior orders for spousal and child support are actually being paid, the court should deduct those payments from the gross income before applying the formula to determine the child support order. This section applies only to orders for child support for children other than those who are the subject of the pending action.

\section{J. EXPENSES OF SUBSEQUENT FAMILIES}

In in stances where the non-custodial parent has remarried and has child ren by a subsequent marriage, the court should examine such circumstances closely to determine in the allocation of available resources whether consideration beyond Part II Section I (Prior Orders of Support) should be given when the custodial parent of children borne of the first marriage, or subsequent marriages appears before the court seeking a modification of the existing child support order. Expenses of a subsequent family may be used as a defense to a request to modify an order seeking an increase in the existing order, but such expenses should not be considered a reason to decrease existing prior orders. In actions pursuant to G.L. c.209C, this paragraph shall be construed to apply equally to children bom out of wedlock. 


\section{CHILD SUPPORT OBLIGATION SCHEDULE}

\section{A. BASIC ORDER}

The basic child support obligation, based upon the incomc of the non-custodial parent is as follows:

GROSS WEEKLY INCOME

$\$ 0-\$ 100$

$\$ 101-\$ 280$

$\$ 281-\$ 750$

\$751-max

\section{1}

Discretion of the court, but not less than $\$ 80$ per month
$24 \%$

$\$ 67+28 \%$

$\$ 59+23 \%$

(\% refers to all dollars over $\$ 280)$

$$
\$ 167+25 \%
$$

$(\%$ refers to all dollars over $\$ 750)$

\section{NUMBER OF CHILDREN}

2

3

For children in excess of 3 covered by the order, the support shall be no less than that for 3 children; should a judge order support at the 3 child level, written findings shall describe the circumstances of the particular case which warrant the minimum order.

Within the discretion of the court, and in consideration of the totality of the circumstances of the parties, the Basic Order may be either increased or decreased by $2 \%$. An adjustment of $2 \%$ shall not be considered a deviation.

\section{B. AGE DIFFERENTIAL}

The above orders are to be increased to reflect the cost of raising older children. The following is intended to be applied to the age of the oldest child in the household for whom support is sought under the pending action.

AGE OF OLDEST CHILD
$0-12$
$13-18$
Over 18

\section{PERCENTAGE INCREASE}

Basic Order Applies

Basic Order $+10 \%$ of Basic Order

Discretion of the court (and if statute permits)

\section{CUSTODIAL PARENT INCOME ADJUSTMENT}

Where the custodial parent works and earns incomc in exccss of $\$ 20,000$ after consideration of child care cxpenses, the support order is to be reduced by the percentage that the excess represents in relation to the combined incomes of both parents minus the custodial parent's disregard. 
All provisions of the Guidelines should be reviewed prior to the completion of the worksheet. These Guidelines will apply (absent a prior agreement acceptable to both parties) in cases where combined gross income of both parties does not exceed $\$ 135,000$ and where the gross income of the non-custodial parent does not exceed \$100,000. Worksheets shall be completed for all cases.

\section{BASIC ORDER}

a. Non custodial gross weekly income (less prior support orders actually paid for child/family other than the family seeking this order)

b. Basic Child Support Order from chart (pp. 8- 11)

(A)

2. ADJUSTMENT FOR AGE OF CHILDREN

a. If age of oldest child is $13-18$, calculate $10 \%$ times (A)

b. Adjusted order $(A)+(2 a)$

(B)

3. CUSTODIAL PARENT INCOME ADJUSTMENT

a. Custodial parent gross income (annual)

b. Less $\$ 20,000$

c. Less annual child care cost

d. Custodial adjusted gross

e. Non custodial gross (annual)

f. Total available gross $(d)+(e)$

g. Line $3(\mathrm{~d})$ Line $3(f)$

h. 3 (d) divided by 3 (f) $\%$

i. Adjustment for custodial income ( Line $3 \mathrm{~h} \%$ ) X (B)

(C)

4. CALCULATION OF FINAL ORDER

a. Adjusted order, (B) above

(B)

b. Less adjustment for (C) above

(C) -

c. Less $50 \%$ weekly cost to obligor of family group health insurance [Section G. 1]

Or

Plus $50 \%$ weekly cost of obligee's family group health insurance [Section G. 1] 


\begin{tabular}{|c|c|c|c|}
\hline \multirow{2}{*}{$\begin{array}{l}\text { Non-Custodial } \\
\text { Gross Weekly } \\
\text { Income }\end{array}$} & \multicolumn{3}{|c|}{ Number of Children } \\
\hline & 1 & 2 & 3 \\
\hline $0-100$ & \multicolumn{3}{|c|}{ Not less than 18.46} \\
\hline 101 & 21 & 24 & 27 \\
\hline 105 & 22 & 25 & 28 \\
\hline 110 & 23 & 26 & 30 \\
\hline 115 & 24 & 28 & 31 \\
\hline 120 & 25 & 29 & 32 \\
\hline 125 & 26 & 30 & 34 \\
\hline 130 & 27 & 31 & 35 \\
\hline 135 & 28 & 32 & 36 \\
\hline 140 & 29 & 34 & 38 \\
\hline 145 & 30 & 35 & 39 \\
\hline 150 & 32 & 36 & 41 \\
\hline 155 & 33 & 37 & 42 \\
\hline 160 & 34 & 38 & 43 \\
\hline 165 & 35 & 40 & 45 \\
\hline 170 & 36 & 41 & 46 \\
\hline 175 & 37 & 42 & 47 \\
\hline 180 & 38 & 43 & 49 \\
\hline 185 & 39 & 44 & 50 \\
\hline 190 & 40 & 46 & 51 \\
\hline 195 & 41 & 47 & 53 \\
\hline 200 & 42 & 48 & 54 \\
\hline 205 & 43 & 49 & 55 \\
\hline 210 & 44 & 50 & 57 \\
\hline 215 & 45 & 52 & 58 \\
\hline 220 & 46 & 53 & 59 \\
\hline 225 & 47 & 54 & 61 \\
\hline 230 & 48 & 55 & 62 \\
\hline 235 & 49 & 56 & 63 \\
\hline 240 & 50 & 58 & 65 \\
\hline 245 & 51 & 59 & 66 \\
\hline 250 & 53 & 60 & 68 \\
\hline 255 & 54 & 61 & 69 \\
\hline 260 & 55 & 62 & 70 \\
\hline 265 & 56 & 64 & 72 \\
\hline 270 & 57 & 65 & 73 \\
\hline 275 & 58 & 66 & 74 \\
\hline 280 & 59 & 67 & 76 \\
\hline 281 & 59 & 67 & 76 \\
\hline 285 & 60 & 68 & 78 \\
\hline 290 & 61 & 70 & 79 \\
\hline 295 & 62 & 71 & 81 \\
\hline 300 & 64 & 73 & 82 \\
\hline 305 & 65 & 74 & 84 \\
\hline 310 & 66 & 75 & 85 \\
\hline 315 & 67 & 77 & 87 \\
\hline 320 & 68 & 78 & 88 \\
\hline 555 & 122 & 144 & 161 \\
\hline 560 & 123 & 145 & 163 \\
\hline 565 & 125 & 147 & 164 \\
\hline
\end{tabular}

\begin{tabular}{|c|c|c|c|}
\hline \multirow{2}{*}{$\begin{array}{c}\text { Non-Custodial } \\
\text { Gross Weekly } \\
\text { Income }\end{array}$} & \multicolumn{3}{|c|}{ Number of Children } \\
\hline & 1 & 2 & 3 \\
\hline 325 & 69 & 80 & 90 \\
\hline 330 & 71 & 81 & 92 \\
\hline 335 & 72 & 82 & 93 \\
\hline 340 & 73 & 84 & 95 \\
\hline 345 & 74 & 85 & 96 \\
\hline 350 & 75 & 87 & 98 \\
\hline 355 & 76 & 88 & 99 \\
\hline 360 & 77 & 89 & 101 \\
\hline 365 & 79 & 91 & 102 \\
\hline 370 & 80 & 92 & 104 \\
\hline 375 & 81 & 94 & 105 \\
\hline 380 & 82 & 95 & 107 \\
\hline 385 & 83 & 96 & 109 \\
\hline 390 & 84 & 98 & 110 \\
\hline 395 & 85 & 99 & 112 \\
\hline 400 & 87 & 101 & 113 \\
\hline 405 & 88 & 102 & 115 \\
\hline 410 & 89 & 103 & 116 \\
\hline 415 & 90 & 105 & 118 \\
\hline 420 & 91 & 106 & 119 \\
\hline 425 & 92 & 108 & 121 \\
\hline 430 & 94 & 109 & 123 \\
\hline 435 & 95 & 110 & 124 \\
\hline 440 & 96 & 112 & 126 \\
\hline 445 & 97 & 113 & 127 \\
\hline 450 & 98 & 115 & 129 \\
\hline 455 & 99 & 116 & 130 \\
\hline 460 & 100 & 117 & 132 \\
\hline 465 & 102 & 119 & 133 \\
\hline 470 & 103 & 120 & 135 \\
\hline 475 & 104 & 122 & 136 \\
\hline 480 & 105 & 123 & 138 \\
\hline 485 & 106 & 124 & 140 \\
\hline 490 & 107 & 126 & 141 \\
\hline 495 & 108 & 127 & 143 \\
\hline 500 & 110 & 129 & 144 \\
\hline 505 & 111 & 130 & 146 \\
\hline 510 & 112 & 131 & 147 \\
\hline 515 & 113 & 133 & 149 \\
\hline 520 & 114 & 134 & 150 \\
\hline 525 & 115 & 136 & 152 \\
\hline 530 & 117 & 137 & 154 \\
\hline 535 & 118 & 138 & 155 \\
\hline 540 & 119 & 140 & 157 \\
\hline 545 & 120 & 141 & 158 \\
\hline 550 & 121 & 143 & 160 \\
\hline 785 & 176 & 210 & 234 \\
\hline 790 & 177 & 211 & 235 \\
\hline 795 & 178 & 213 & 237 \\
\hline
\end{tabular}




\begin{tabular}{|c|c|c|c|}
\hline \multirow{2}{*}{$\begin{array}{l}\text { Non-Custodial } \\
\text { Gross Weekly } \\
\text { Income }\end{array}$} & \multicolumn{3}{|c|}{ Number of Children } \\
\hline & 1 & 2 & 3 \\
\hline 570 & 126 & 148 & 166 \\
\hline 575 & 127 & 150 & 167 \\
\hline 580 & 128 & 151 & 169 \\
\hline 585 & 129 & 152 & 171 \\
\hline 590 & 130 & 154 & 172 \\
\hline 595 & 131 & 155 & 174 \\
\hline 600 & 133 & 157 & 175 \\
\hline 605 & 134 & 158 & 177 \\
\hline 610 & 135 & 159 & 178 \\
\hline 615 & 136 & 161 & 180 \\
\hline 620 & 137 & 162 & 181 \\
\hline 625 & 138 & 164 & 183 \\
\hline 630 & 140 & 165 & 185 \\
\hline 635 & 141 & 166 & 186 \\
\hline 640 & 142 & 168 & 188 \\
\hline 645 & 143 & 169 & 189 \\
\hline 650 & 144 & 171 & 191 \\
\hline 655 & 145 & 172 & 192 \\
\hline 660 & 146 & 173 & 194 \\
\hline 665 & 148 & 175 & 195 \\
\hline 670 & 149 & 176 & 197 \\
\hline 675 & 150 & 178 & 198 \\
\hline 680 & 151 & 179 & 200 \\
\hline 685 & 152 & 180 & 202 \\
\hline 690 & 153 & 182 & 203 \\
\hline 695 & 154 & 183 & 205 \\
\hline 700 & 156 & 185 & 206 \\
\hline 705 & 157 & 186 & 208 \\
\hline 710 & 158 & 187 & 209 \\
\hline 715 & 159 & 189 & 211 \\
\hline 720 & 160 & 190 & 212 \\
\hline 725 & 161 & 192 & 214 \\
\hline 730 & 163 & 193 & 216 \\
\hline 735 & 164 & 194 & 217 \\
\hline 740 & 165 & 196 & 219 \\
\hline 745 & 166 & 197 & 220 \\
\hline 750 & 167 & 199 & 222 \\
\hline 751 & 167 & 199 & 222 \\
\hline 755 & 168 & 201 & 224 \\
\hline 760 & 170 & 202 & 225 \\
\hline 765 & 171 & 204 & 227 \\
\hline 770 & 172 & 205 & 229 \\
\hline 775 & 173 & 207 & 230 \\
\hline 780 & 175 & 208 & 232 \\
\hline 1020 & 235 & 280 & 311 \\
\hline 1025 & 236 & 282 & 313 \\
\hline 1030 & 237 & 283 & 314 \\
\hline 1035 & 238 & 285 & 316 \\
\hline 1040 & 240 & 286 & 318 \\
\hline 1045 & 241 & 288 & 319 \\
\hline
\end{tabular}

\begin{tabular}{|c|c|c|c|}
\hline Non-Custodial & \multicolumn{3}{|c|}{ Number of Children } \\
\cline { 2 - 4 } Gross Weekly & & & \\
Income & 1 & 2 & 3 \\
\hline 800 & 180 & 214 & 239 \\
805 & 181 & 216 & 240 \\
810 & 182 & 217 & 242 \\
815 & 183 & 219 & 243 \\
820 & 185 & 220 & 245 \\
825 & 186 & 222 & 247 \\
830 & 187 & 223 & 248 \\
835 & 188 & 225 & 250 \\
840 & 190 & 226 & 252 \\
845 & 191 & 228 & 253 \\
850 & 192 & 229 & 255 \\
855 & 193 & 231 & 257 \\
860 & 195 & 232 & 258 \\
865 & 196 & 234 & 260 \\
870 & 197 & 235 & 262 \\
875 & 198 & 237 & 263 \\
880 & 200 & 238 & 265 \\
885 & 201 & 240 & 267 \\
890 & 202 & 241 & 268 \\
895 & 203 & 243 & 270 \\
900 & 205 & 244 & 272 \\
905 & 206 & 246 & 273 \\
910 & 207 & 247 & 275 \\
915 & 208 & 249 & 276 \\
920 & 210 & 250 & 278 \\
925 & 211 & 252 & 280 \\
930 & 212 & 253 & 281 \\
935 & 213 & 255 & 283 \\
940 & 215 & 256 & 285 \\
945 & 216 & 258 & 286 \\
950 & 217 & 259 & 288 \\
955 & 218 & 261 & 290 \\
960 & 220 & 262 & 291 \\
965 & 221 & 264 & 293 \\
970 & 222 & 265 & 295 \\
975 & 223 & 267 & 296 \\
980 & 225 & 268 & 298 \\
985 & 226 & 270 & 300 \\
990 & 227 & 271 & 301 \\
995 & 228 & 273 & 303 \\
1000 & 230 & 274 & 305 \\
1005 & 231 & 276 & 306 \\
1010 & 232 & 277 & 308 \\
1015 & 233 & 279 & 309 \\
\hline 1255 & 293 & 351 & 389 \\
1260 & 295 & 352 & 390 \\
1265 & 296 & 354 & 392 \\
1270 & 297 & 355 & 394 \\
& 298 & 357 & 395 \\
& 300 & 358 & 397
\end{tabular}




\begin{tabular}{|c|c|c|c|}
\hline \multirow{2}{*}{$\begin{array}{l}\text { Non-Custodial } \\
\text { Gross Weekly } \\
\text { Income }\end{array}$} & \multicolumn{3}{|c|}{ Number of Children } \\
\hline & 1 & 2 & 3 \\
\hline 1050 & 242 & 289 & 321 \\
\hline 1055 & 243 & 291 & 323 \\
\hline 1060 & 245 & 292 & 324 \\
\hline 1065 & 246 & 294 & 326 \\
\hline 1070 & 247 & 295 & 328 \\
\hline 1075 & 248 & 297 & 329 \\
\hline 1080 & 250 & 298 & 331 \\
\hline 1085 & 251 & 300 & 333 \\
\hline 1090 & 252 & 301 & 334 \\
\hline 1095 & 253 & 303 & 336 \\
\hline 1100 & 255 & 304 & 338 \\
\hline 1105 & 256 & 306 & 339 \\
\hline 1110 & 257 & 307 & 341 \\
\hline 1115 & 258 & 309 & 342 \\
\hline 1120 & 260 & 310 & 344 \\
\hline 1125 & 261 & 312 & 346 \\
\hline 1130 & 262 & 313 & 347 \\
\hline 1135 & 263 & 315 & 349 \\
\hline 1140 & 265 & 316 & 351 \\
\hline 1145 & 266 & 318 & 352 \\
\hline 1150 & 267 & 319 & 354 \\
\hline 1155 & 268 & 321 & 356 \\
\hline 1160 & 270 & 322 & 357 \\
\hline 1165 & 271 & 324 & 359 \\
\hline 1170 & 272 & 325 & 361 \\
\hline 1175 & 273 & 327 & 362 \\
\hline 1180 & 275 & 328 & 364 \\
\hline 1185 & 276 & 330 & 366 \\
\hline 1190 & 277 & 331 & 367 \\
\hline 1195 & 278 & 333 & 369 \\
\hline 1200 & 280 & 334 & 371 \\
\hline 1205 & 281 & 336 & 372 \\
\hline 1210 & 282 & 337 & 374 \\
\hline 1215 & 283 & 339 & 375 \\
\hline 1220 & 285 & 340 & 377 \\
\hline 1225 & 286 & 342 & 379 \\
\hline 1230 & 287 & 343 & 380 \\
\hline 1235 & 288 & 345 & 382 \\
\hline 1240 & 290 & 346 & 384 \\
\hline 1245 & 291 & 348 & 385 \\
\hline 1250 & 292 & 349 & 387 \\
\hline 1490 & 352 & 421 & 466 \\
\hline 1495 & 353 & 423 & 468 \\
\hline 1500 & 355 & 424 & 470 \\
\hline 1505 & 356 & 426 & 471 \\
\hline 1510 & 357 & 427 & 473 \\
\hline 1515 & 358 & 429 & 474 \\
\hline 1520 & 360 & 430 & 476 \\
\hline 1525 & 361 & 432 & 478 \\
\hline 1530 & 362 & 433 & 479 \\
\hline
\end{tabular}

\begin{tabular}{|c|c|c|c|}
\hline \multirow{2}{*}{$\begin{array}{l}\text { Non-Custodial } \\
\text { Gross Weekly } \\
\text { Income }\end{array}$} & \multicolumn{3}{|c|}{ Number of Children } \\
\hline & 1 & 2 & 3 \\
\hline 1285 & 301 & 360 & 399 \\
\hline 1290 & 302 & 361 & 400 \\
\hline 1295 & 303 & 363 & 402 \\
\hline 1300 & 305 & 364 & 404 \\
\hline 1305 & 306 & 366 & 405 \\
\hline 1310 & 307 & 367 & 407 \\
\hline 1315 & 308 & 369 & 408 \\
\hline 1320 & 310 & 370 & 410 \\
\hline 1325 & 311 & 372 & 412 \\
\hline 1330 & 312 & 373 & 413 \\
\hline 1335 & 313 & 375 & 415 \\
\hline 1340 & 315 & 376 & 417 \\
\hline 1345 & 316 & 378 & 418 \\
\hline 1350 & 317 & 379 & 420 \\
\hline 1355 & 318 & 381 & 422 \\
\hline 1360 & 320 & 382 & 423 \\
\hline 1365 & 321 & 384 & 425 \\
\hline 1370 & 322 & 385 & 427 \\
\hline 1375 & 323 & 387 & 428 \\
\hline 1380 & 325 & 388 & 430 \\
\hline 1385 & 326 & 390 & 432 \\
\hline 1390 & 327 & 391 & 433 \\
\hline 1395 & 328 & 393 & 435 \\
\hline 1400 & 330 & 394 & 437 \\
\hline 1405 & 331 & 396 & 438 \\
\hline 1410 & 332 & 397 & 440 \\
\hline 1415 & 333 & 399 & 441 \\
\hline 1420 & 335 & 400 & 443 \\
\hline 1425 & 336 & 402 & 445 \\
\hline 1430 & 337 & 403 & 446 \\
\hline 1435 & 338 & 405 & 448 \\
\hline 1440 & 340 & 406 & 450 \\
\hline 1445 & 341 & 408 & 451 \\
\hline 1450 & 342 & 409 & 453 \\
\hline 1455 & 343 & 411 & 455 \\
\hline 1460 & 345 & 412 & 456 \\
\hline 1465 & 346 & 414 & 458 \\
\hline 1470 & 347 & 415 & 460 \\
\hline 1475 & 348 & 417 & 461 \\
\hline 1480 & 350 & 418 & 463 \\
\hline 1485 & 351 & 420 & 465 \\
\hline 1710 & 407 & 487 & 539 \\
\hline 1715 & 408 & 489 & 540 \\
\hline 1720 & 410 & 490 & 542 \\
\hline 1725 & 411 & 492 & 544 \\
\hline 1730 & 412 & 493 & 545 \\
\hline 1735 & 413 & 495 & 547 \\
\hline 1740 & 415 & 496 & 549 \\
\hline 1745 & 416 & 498 & 550 \\
\hline 1750 & 417 & 499 & 552 \\
\hline
\end{tabular}




\begin{tabular}{|c|c|c|c|}
\hline \multirow{2}{*}{$\begin{array}{l}\text { Non-Custodial } \\
\text { Gross Weekly } \\
\text { Income }\end{array}$} & \multicolumn{3}{|c|}{ Number of Children } \\
\hline & 1 & 2 & 3 \\
\hline 1535 & 363 & 435 & 481 \\
\hline 1540 & 365 & 436 & 483 \\
\hline 1545 & 366 & 438 & 484 \\
\hline 1550 & 367 & 439 & 486 \\
\hline 1555 & 368 & 441 & 488 \\
\hline 1560 & 370 & 442 & 489 \\
\hline 1565 & 371 & 444 & 491 \\
\hline 1570 & 372 & 445 & 493 \\
\hline 1575 & 373 & 447 & 494 \\
\hline 1580 & 375 & 448 & 496 \\
\hline 1585 & 376 & 450 & 498 \\
\hline 1590 & 377 & 451 & 499 \\
\hline 1595 & 378 & 453 & 501 \\
\hline 1600 & 380 & 454 & 503 \\
\hline 1605 & 381 & 456 & 504 \\
\hline 1610 & 382 & 457 & 506 \\
\hline 1615 & 383 & 459 & 507 \\
\hline 1620 & 385 & 460 & 509 \\
\hline 1625 & 386 & 462 & 511 \\
\hline 1630 & 387 & 463 & 512 \\
\hline 1635 & 388 & 465 & 514 \\
\hline 1640 & 390 & 466 & 516 \\
\hline 1645 & 391 & 468 & 517 \\
\hline 1650 & 392 & 469 & 519 \\
\hline 1655 & 393 & 471 & 521 \\
\hline 1660 & 395 & 472 & 522 \\
\hline 1665 & 396 & 474 & 524 \\
\hline 1670 & 397 & 475 & 526 \\
\hline 1675 & 398 & 477 & 527 \\
\hline 1680 & 400 & 478 & 529 \\
\hline 1685 & 401 & 480 & 531 \\
\hline 1690 & 402 & 481 & 532 \\
\hline 1695 & 403 & 483 & 534 \\
\hline 1700 & 405 & 484 & 536 \\
\hline 1705 & 406 & 486 & 537 \\
\hline
\end{tabular}

\begin{tabular}{|c|c|c|c|}
\hline \multirow{2}{*}{$\begin{array}{l}\text { Non-Custodial } \\
\text { Gross Weekly } \\
\text { Income }\end{array}$} & \multicolumn{3}{|c|}{ Number of Children } \\
\hline & 1 & 2 & 3 \\
\hline 1755 & 418 & 501 & 554 \\
\hline 1760 & 420 & 502 & 555 \\
\hline 1765 & 421 & 504 & 557 \\
\hline 1770 & 422 & 505 & 559 \\
\hline 1775 & 423 & 507 & 560 \\
\hline 1780 & 425 & 508 & 562 \\
\hline 1785 & 426 & 510 & 564 \\
\hline 1790 & 427 & 511 & 565 \\
\hline 1795 & 428 & 513 & 567 \\
\hline 1800 & 430 & 514 & 569 \\
\hline 1805 & 431 & 516 & 570 \\
\hline 1810 & 432 & 517 & 572 \\
\hline 1815 & 433 & 519 & 573 \\
\hline 1820 & 435 & 520 & 575 \\
\hline 1825 & 436 & 522 & 577 \\
\hline 1830 & 437 & 523 & 578 \\
\hline 1835 & 438 & 525 & 580 \\
\hline 1840 & 440 & 526 & 582 \\
\hline 1845 & 441 & 528 & 583 \\
\hline 1850 & 442 & 529 & 585 \\
\hline 1855 & 443 & 531 & 587 \\
\hline 1860 & 445 & 532 & 588 \\
\hline 1865 & 446 & 534 & 590 \\
\hline 1870 & 447 & 535 & 592 \\
\hline 1875 & 448 & 537 & 593 \\
\hline 1880 & 450 & 538 & 595 \\
\hline 1885 & 451 & 540 & 597 \\
\hline 1890 & 452 & 541 & 598 \\
\hline 1895 & 453 & 543 & 600 \\
\hline 1900 & 455 & 544 & 602 \\
\hline 1905 & 456 & 546 & 603 \\
\hline 1910 & 457 & 547 & 605 \\
\hline 1915 & 458 & 549 & 606 \\
\hline 1920 & 460 & 550 & 608 \\
\hline 1923 & 460 & 551 & 609 \\
\hline
\end{tabular}




\section{SAMPLE WORKSHEET}

Non custodial parent gross annual income

Weekly support paid - child of prior marriage

Custodial parent gross annual income

2 Children covered by order, ages 6 and 8

Annualized day care cost

Non custodial weekly cost family group health insur.
$\$ 40,000(\$ 769 /$ wcck $)$

$\$ 40$

$\$ 28,000$

$\$ 4,160$

$\$ 24$

1. BASIC ORDER

a. Non custodial gross weekly income (less prior support orders actually paid for child/family other than the family seeking this orda)

b. Basic Child Support Order from chart (pp.8-11)

(A)

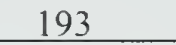

2. ADJUSTMENT FOR AGE OF CHILDREN
a. If age of oldest child is $13-18$, calculate $10 \%$ times (A)

b. Adjusted order (A) + (2a)

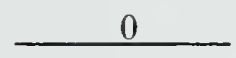

(B) 193

3. CUSTODIAL PARENT INCOME ADJUSTMENT

a. Custodial parent gross income (annual) 28,000

b. Less $\$ 20,000$ $-\$ 20,000$

c. Less annual child care cost $-4,160$

d. Custodial adjusted gross 3,840

e. Non custodial gross (annual) 40,000

f. Total available gross (d ) +(e) 43,840

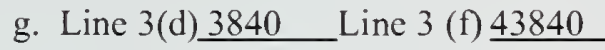

h. 3 (d) divided by 3 (f) $09 \%$

i. Adjustment for custodial income ( Line $3 \mathrm{~h} \%$ ) X (B)

(C) 17

\section{CALCULATION OF FINAL ORDER}

a. Adjusted order, (B) above

(B) 193

b. Less adjustment for (C) above

(C) 17.

c. Less $50 \%$ weekly cost to obligor of family group health insurance [Section G. 1]

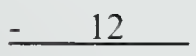

$$
\text { Or }
$$

Plus $50 \%$ weekly cost of obligee's family group hcalth insurance [Section G. 1] 